MATH DIDACTIC: JURNAL PENDIDIKAN MATEMATIKA

Volume 4 Edisi Dies Natalis XXXII, halaman 327 - 335

Tersedia Daring pada http://jurnal.stkipbjm.ac.id/index.php/math

\title{
TINGKAT KECEMASAN DAN PENGARUHNYA TERHADAP HASIL BELAJAR SISWA PADA PELAJARAN MATEMATIKA
}

\section{LEVEL OF ANXIETY AND ITS EFFECT ON STUDENT LEARNING OUTCOMES IN MATHEMATICS \\ Nurhayati Sri Utami, Nyiayu Fahriza Fuadiah \\ Universitas Islam Negeri Raden Fatah Palembang \\ nurhayati.sri.utami22@gmail.com,nyiayufahriza@univ-pgri-palembang.ac.id}

\begin{abstract}
Abstrak: Penelitian ini bertujuan untuk mengetahui bagaimana tingkat kecemasan yang dialami oleh siswa dan pengaruhnya terhadap hasil belajar pada pembelajaran matematika. Dilatar belakangi oleh munculnya kecemasan yang dialami siswa pada pelajaran matematika yang mempengaruhi hasil belajar siswa. Penetitian ini menggunakan penelitian kuantitatif dengan metode One-Shot Case Study. Subjek penelitian ini adalah 30 siswa kelas VIII SMPN 40 Palembang yang terdiri dari 14 laki-laki dan 16 perempuan. Data yang digunakan merupakan data sekunder yang berupa data kecemasan siswa dan data hasil belajar pada pembelajaran matematika. Analisis data pada penelitian ini menggunakan uji normalitas One-Sample Kolmogorov-Smirnov sedangkan untuk melihat pengaruh kecemasan yang dialami oleh siswa dilakukan dengan uji statistik non parametris korelasional dengan uji Spearman Rank. Pengujian dilakukan menggunakan aplikasi IBM SPSS 24. Hasil penetian ini menunjukan bahwa kecemasan matematika siswa SMPN 40 Palembang mayoritas termasuk pada tingkat kategori sedang dengan presentase sebesar $57 \%$ dan pengaruh antara kecemasan terhadap hasil belajar siswa pada pembelajaran matematika tidaklah signifikan, namun semakin tinggi nilai kecemasan siswa maka semakin rendah hasil belajarnya.
\end{abstract}

Kata Kunci: kecemasan, hasil belajar, pelajaran matematika

\begin{abstract}
This study aims to determine how the level of anxiety experienced by students and their influence on learning outcomes in mathematics learning. Background by the emergence of anxiety experienced by students in mathematics lessons that affect student learning outcomes. This research uses quantitative research using the OneShot Case Study method. The subjects of this study were 30 students of class VIII of SMP 40 Palembang consisting of 14 men and 16 women. The data used is secondary data in the form of student anxiety data and learning outcomes data in mathematics learning. Data analysis in this study using the Kolmogorov-Smirnov One-Sample normality test while to see the effect of anxiety experienced by students was done by correlational non-parametric statistical test with the Spearman Rank test. Tests are carried out using IBM SPSS 24 application. The results of this determination show that the majority of mathematics anxiety in Palembang's 40th Junior High School students is included in the medium category with a percentage of 57\% and the influence of anxiety on student learning outcomes in mathematics learning is not significant, but the higher student anxiety scores then the lower the learning outcomes.
\end{abstract}

Keyword: anxiety, learning outcomes, math lessons

Cara Sitasi: Utami, N.S., \& Fuadiah, N.F. (2018). Tingkat kecemasan dan pengaruhnya terhadap hasil belajar siswa pada pelajaran matematika. Math Didactic: Jurnal Pendidikan Matematika, 4 Edisi Dies Natalis XXXII, 327-335. 
Matematika merupakan salah satu pelajaran wajib yang diperoleh siswa dari taman kanak-kanak hingga perguruan tinggi. Hal tersebut dikarenakan betapa pentingnya matematika dalam kehidupan.

Dalam masyarakat awam hasil belajar merupakan tolak ukur kecerdasan seorang siswa terutama pada pelajaran matematika. Siswa dituntut memiliki hasil belajar yang memuaskan pada pelajaran matematika. Kenapa demikian? Ini dikarenakan persepsi buruk terhadap pelajaran matematika didalam kalangan masyarakat dan keluarga yang menjadi tempat pembelajaran pertama bagi seorang anak. Sebagian besar siswa beranggapan pelajaran matematika merupakan pelajaran yang sulit berdasarkan anggapan dari keluarga. Apabila anggapan seperti itu terus dibiarkan, akan mengakibatkan merasa terpaksanya siswa untuk belajar matematika (Priyanto, D, Sugianto dan Sri Riyanti, 2017, hal 2). Hal ini juga dikemukakan Wicaksono, A. B. (2013, hal 12) bahwa persepsi yang berkembang di tengah masyarakat bahwa matematika itu sulit telah terkooptasi sebagian pikiran anak. Hambatan atau kesulitan belajar matematika dapat dialami oleh siswa dengan berbagai tingkat kemampuan dan kelompok manapun, tidak hanya dialami oleh siswa yang berkemampuan 'rendah' tetapi dapat juga dialami oleh siswa dengan tingkat kemampuan 'baik'(Fuadiah, 2017, hal 24).

Hasil belajar siswa dipengaruhi oleh faktor-faktor yang terjadi selama proses pembelajaran, Faktor internal terdiri dari kemampuan belajar, motivasi belajar, minta dan perhatian, sikap dan kebiadaan belajar serta fisik dan psikis sedangkan faktor eksternal yaitu lingkungan. Faktor lingkungan yang dekat dengan siswa yakni masyarakat (Hadiyanto, 2016, hal 22). Demikian pandangan atau pola pikir masyarakat terhadap hasil belajar siswa memiliki pengaruh terhadap siswa. Pola pikir, tekanan serta keterpaksaan yang ditimbulkan menyebabkan anak hanya berorientasi pada hasil dan nilai saja bukan proses pembelajaran itu sendiri. Ketika seorang anak mendapat nilai yang jelek, dia menjadi tertekan dan menganggap dirinya bodoh. Keterpaksaan dan tekanan tersebut memicu gejala-gelaja kecemasan pada siswa.

Kecemasan merupakan suatu gejala normal yang terjadi. Kecemasan dianggap sebagai salah satu faktor penghambat dalam belajar yang dapat menggangu kinerja fungsi kognitif seseorang dalam berkonsentarsi, mengingat, pembentukan konsep, dan pemecahan masalah (Ekawati, 2015, hal 165). Kecemasan yang dialami pada pembelajaran matematika itu disebut kecemasan matematika (math anxiety). Kecemasan matematika adalah jenis penyakit, kecemasan matematika mengacu pada suasana hati yang tidak sehat seperti respon yang terjadi ketika beberapa siswa mengalami permasalahan matematika dan menampakkan dirinya dengan panik dan hilangnya pikiran, depresi, dan tidak berdaya, gugup, dan takut, dan sebagainya (Lou, 2009, hal 12-13).

Kecemasan matematika sangat lah rentan terjadi pada siswa sekolah menengah pertama (SMP). Mengapa demikian? ini karena pada masa belasan tahunlah kecemasan sosial berkembang (Arvin, 2000, hal 103). Kecemasan sosial ini terkait dengan hubungan sosial seorang siswa. Siswa rentan mengalami traumatis yang disebabkan tekanan, ejekan teman, tidak adanya kepercayaan diri dan sebagainya. Traumatis ini juga menjadi pemicu timbulnya kecemasan. Kecemasan itu terjadi pada diri siswa tidak hanya dialami oleh siswa dengan kemampuan rendah saja, melainkan siswa dengan kemampuan tinggi 
dapat mengalami kecemasan yang tinggi pula (Noor, 2017, hal 176).

Hubungan antara kecemasan dan hasil belajar terlihat dari beberapa hasil penelitian yang menyatakan bahwa semakin tinggi tingkat kecemasan maka semakin rendah prestasi belajar matematika. Seperti halnya pada penelitian Ekawati (2015, hal 168) bahwa ada pengaruh antara kecemasan terhadap hasil belajar matematika siswa kelas VII SMPN 13 Banjarmasin. Kemudian Sejalan dengan penelitian tersebut menurut Lou (2009, hal 18) bahwa kecemasan matematika dapat dipengaruhi oleh penampilan matematika, minat matematika, kecemasan diri, perbedaan gender dan perbedaan kelas. Misalnya pada kecemasan matematika yang mempengaruhi kecemasan diri siswa bahwa semakin percaya diri siswa, semakin rendah kecemasan matematika yang mereka miliki; perasaan siswa yang kurang percaya diri maka kecemasan matematika yang mereka miliki akan semakin tinggi. Dari uraian tersebut peneliti tertarik meneliti karena sangat penting bagi seorang guru sebagai pendidik dapat mengetahui tingkat kecemasan yang dialami siswa dan seberapa besar kecemasan siswa mempengaruhi pencapaian siswa dalam hasil belajar pelajaran matematika.

\section{Metode Penelitian}

Penelitian ini merupakan penelitian Kuantitatif dengan metode OneShot Case Study dimana kecemasan siswa sebagai treatment atau Variabel Indenpenden $(X)$ dan hasil belajar sebagai hasil atau observasi $(O)$. Penelitian ini dilaksanakan di SMN 40 Palembang, dengan subjek penelitiannya siswa kelas VIII yakni kelas VIII.4 yang berjumlah 30 orang dengan teknik Sampling Purposive atas pertimbangan dari guru Wali Kelas dan keberagaman siswa dikelas tersebut.

Pengumpulan data pada penelitian ini menggunakan instrumen yakni soal tes, dan angket. Soal tes merupakan tes perseorangan yang tersdiri dari soal ulangan harian siswa pada materi pola bilangan dengan jumlah soal sebanyak 3 soal. Angket yang digunakan pada penelitian ini adalah angket untuk melihat tingkat kecemasan siswa terhadap pembelajaran matematika yang meliputi dari aspek kognitif, afektif, psikomotorik dan somatik siswa yang dijabarkan melalui kriteria-kriteria. Kemudian, kriteria-kriteria tersebut dituangkan dalam bentuk butir-butir pertanyaan. Penyataan-pernyataan dalam angket tersebut dinyatakan dalam 2 bentuk, yaitu pernyataan yang bersifat positif pada pernyataan yang memperlihatkan adanya kecemasan pada siswa dan pernyataan yang bersifat negatif pada pernyataan yang mmperlihatkan tidak adanya kecemasan pada siswa. Angket ini menggunakan skala Likert dengan 4 alternatif pilihan, yaitu sangat setuju (SS), Setuju (S), jarang(J) dan tidak pernah (TP). Berikut tabel indikator beserta bentuk item pada angket kecemasan siswa.

Tabel 1. Indikator angket kecemasan siswa

\begin{tabular}{llccc}
\hline No. & Aspek & \multicolumn{2}{c}{ Bentuk Item } & Jumlah \\
\cline { 3 - 4 } & & Positif & Negatif & Item \\
1. & Kognitif & 7 & 0 & 7 \\
2. & Afektif & 3 & 9 & 12 \\
3. & Psikomotor & 2 & 2 & 4 \\
4. & Somatik & 2 & 7 & 9 \\
\hline
\end{tabular}

Tabel diatas mencakup semua kriteria kecemasan matematika, sedangkan pengelompokan item berdasarkan kriterianya dapat dilihat pada tabel berikut:

Tabel 2. Kriteria angket kecemasan siswa 


\begin{tabular}{|c|c|c|c|}
\hline$\overline{\text { No. }}$ & Kriteria & Nomor Item & $\begin{array}{c}\text { Jumlah } \\
\text { Item }\end{array}$ \\
\hline 1. & $\begin{array}{l}\text { Kecemasan siswa } \\
\text { sebelum menghadapi } \\
\text { pembelajaran }\end{array}$ & 26,31 & 2 \\
\hline 2. & $\begin{array}{l}\text { Kecemasan siswa saat } \\
\text { menghadapi } \\
\text { pembelajaran }\end{array}$ & $\begin{array}{c}2,3,4,8,9, \\
11,12,14,15, \\
16,18,20,28, \\
29,30,32\end{array}$ & 16 \\
\hline 3. & $\begin{array}{l}\text { Kecemasan siswa } \\
\text { setelah menghadapi } \\
\text { pembelajaran }\end{array}$ & 1,5 & 2 \\
\hline 4. & $\begin{array}{l}\text { Kecemasan siswa } \\
\text { sebelum menghadapi } \\
\text { tes }\end{array}$ & $6,17,24,27$ & 4 \\
\hline
\end{tabular}

5. Kecemasan siswa saat $7,21,22,23, \quad 5$ menghadapi tes

25

6. Kecemasan siswa $10,13,19, \quad 3$ setelah menghadapi tes

Analisis data pada penelitian ini diawali dengan mengkategorikan tingkat kecemasan yang dialami siswa. Tingkat kecemasan siswa di kategorikan menjadi 3 kategori yaitu kategori tinggi, kategori sedang dan kategori rendah (Hidayah, 2016, hal 43). Adapun ketentuan pengkategorian tersebut sebagai berikut:

1. Kategori tinggi $: X \geq \mu+1 \sigma$

2. Kategori sedang : $\mu-1 \sigma \leq X<\mu+1 \sigma$

3. Kategori rendah :X $<\mu-1 \sigma$

Data di analisis uji statistik non parametris untuk mengetahui normalitas dengan uji One-Sample Kolmogorov-Smirnov Untuk melihat pengaruh kecemasan yang dialami oleh siswa dilakukan dengan uji statistik non parametris korelasional dengan uji Spearman Rank. Pengujian dilakukan menggunakan aplikasi IBM SPSS 24.

\section{Hasil Penelitian dan Pembahasan}

\section{Hasil}

Berdasarkan tabel 3, dapat dibuat menjadi menjadi diagram batang seperti pada

Gambar 1. Diagram distribusi frekuensi kecemasan siswa

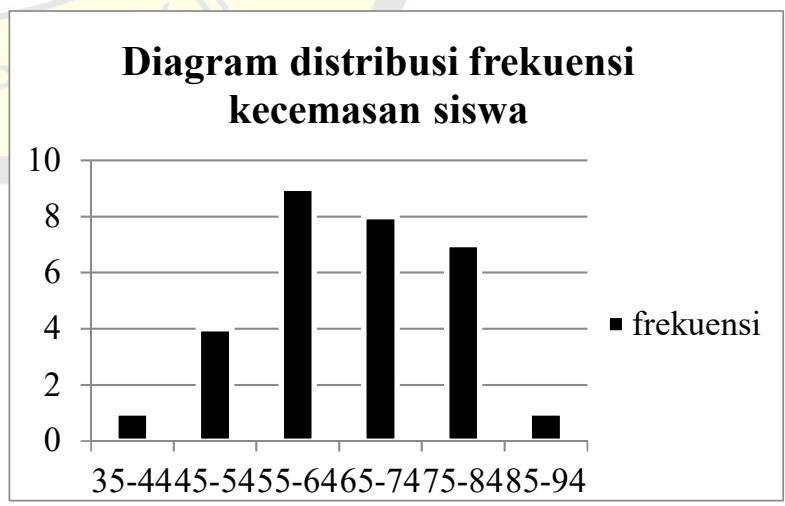

Dari tabel dan diagram tersebut terlihat bahwa frekuensi skor kecemasan siswa paling banyak berada pada interval kelas ke-3 gambar berikut ini: kecemasan siswa dan hasil belajar siswa terhadap pembelajaran matematika didapat kan rata-rata skor kecemasan matematika adalah sebesar 65,2 dan simpangan baku adalah sebesar 11,88 sedangkan rata-rata hasil belajar siswa pada materi pola bilangan adalah 32,75 dan simpangan baku adalah sebesar 26 . Hasil penskoran angket siswa kelas VIII disajikan dalam bentuk tabel distribusi frekuensi dan kategori skor berikut.

\section{Tabel 3.Tabel Distribusi Frekuensi Kecemasan Siswa}

\begin{tabular}{clll}
\hline No. & $\begin{array}{l}\text { Interval } \\
\text { kelas }\end{array}$ & frekuensi & $\begin{array}{l}\text { frekuensi } \\
\mathbf{( 1 0 0 \% )}\end{array}$ \\
\hline 1. & $35-44$ & 1 & $3 \%$ \\
\hline 2. & $45-54$ & 4 & $13 \%$ \\
\hline 3. & $55-64$ & 9 & $30 \%$ \\
\hline 4. & $65-74$ & 8 & $27 \%$ \\
\hline 5. & $75-84$ & 7 & $23 \%$ \\
\hline 6. & $85-94$ & 1 & $3 \%$ \\
Jumlah & 30 & $100 \%$ \\
\hline
\end{tabular}


dengan skor 55-64 pada presentase 30\% sedangkan frekuensi skor kecemasan siswa paling sedikit berada pada 2 interval kelas yakni pada interval kelas 35-44 dan interval kelas 85-94 pada presentase 3\%.

Selanjutnya dikategorikan tingkat kecemasan yang di alami oleh siswa pada tabel berikut:

Tabel 4. Kategorisasi Tingkat Kecemasan Siswa

\begin{tabular}{lllll}
\hline No. & Skor & $\begin{array}{l}\text { Frekuen } \\
\text { si }\end{array}$ & $\begin{array}{l}\text { Frekuensi } \\
\text { Relatif }\end{array}$ & $\begin{array}{l}\text { Katego } \\
\text { ri }\end{array}$ \\
\hline 1. & $X \geq 77$ & 5 & $17 \%$ & Rendah \\
2. & $\begin{array}{l}53,4 \leq X \\
<77\end{array}$ & 17 & $57 \%$ & Sedang \\
3. & $X<53,4$ & 8 & $27 \%$ & Tinggi \\
\hline
\end{tabular}

Berdasarkan pengkategorian skor kecemasan siswa tersebut dapat diketahui bahwa kecemasan matematika siswa sekolah tersebut mayoritas termasuk kedalam kategori sedang dengan presentase sebesar 57\%.

Dalam penelitian ini dilakukan 2 uji. Pertama, uji normalitas data dengan statistik non parametrik yakni dengan uji One-Sample Kolmogorov-Smirnov Test berbantuan aplikasi SPSS 24. Kedua, uji hipotesis dengan korelasi Spearman Rank berbantuan aplikasi SPSS 24.

\section{Uji Normalitas}

Untuk mengetahui data tersebut normal atau tidak data diuji statistik dengan korelasi One-Sample Kolmogorov-Smirnov Test. Adapun langkah-langkah uji Hipotesis sebagai berikut:

1. Menentukan Hipotesis

$$
\begin{array}{ll}
H_{0} & : \text { data berdistribusi normal; } \\
H_{1} & \text { : data tidak berdistribusi } \\
& \text { normal. }
\end{array}
$$

2. $\alpha=5 \%$
3. Uji statistik menggunakan SPSS

Hasil uji data dengan statistik nonparametrik teerdeskripsi dalam tabel berikut.

\begin{tabular}{|c|c|c|}
\hline & & $\begin{array}{l}\text { Unstandardized } \\
\text { Residual }\end{array}$ \\
\hline \multicolumn{2}{|l|}{$\mathrm{N}$} & 30 \\
\hline \multirow{2}{*}{$\begin{array}{l}\text { Normal } \\
\text { Parameters }^{\mathrm{a}, \mathrm{b}}\end{array}$} & Mean & ,0000000 \\
\hline & Std. Deviation & 11,43497904 \\
\hline \multicolumn{2}{|c|}{ Most ExtremeAbsolute } & , 106 \\
\hline \multirow[t]{2}{*}{ Differences } & Positive & ,082 \\
\hline & Negative &,- 106 \\
\hline \multicolumn{2}{|l|}{ Test Statistic } & , 106 \\
\hline \multicolumn{2}{|c|}{ Asymp. Sig. (2-tailed) } & $200^{\mathrm{c}, \mathrm{d}}$ \\
\hline
\end{tabular}

Tabel 5. Tabel Uji One-Sample Kolmogorov-Smirnov Test

a. Test distribution is Normal.

b. Calculated from data.

c. Lilliefors Significance Correction.

$\mathrm{d}$. This is a lower bound of the true significance.

Dari uji normalitas kolmogorovsmirnov tersebut dapat diketahui bahwa nilai signifikansi sebesar 0,2>0,05, sehingga $H_{0}$ diterima dapat disimpulkan bahwa data yang diuji berdistribusi normal.

\section{Uji Hipotesis}

Untuk mengetahui pengaruh kecemasan terhadap hasil belajar siswa data diuji statistik untuk mengukur hubungan antara dua variabel tersebut dengan korelasi Spearman Rank. Adapun langkah-langkah uji Hipotesis sebagai berikut:

1. Menentukan Hipotesis

$H_{0} \quad$ : tidak terdapat hubungan yang signifikan antara kecemasan matematika dengan hasil belajar matematika siswa;

$H_{1} \quad$ : terdapat hubungan yang 
signifikan antara kecemasan matematika dengan hasil belajar matematika siswa

2. $\alpha=5 \%$

3. Uji statistik menggunakan SPSS

Hasil uji data dengan statistik nonparametrik teerdeskripsi dalam tabel berikut.

Tabel 6. Tabel Hasil Korelasi Spearman Rank

\begin{tabular}{|c|c|c|c|c|}
\hline & & & $\begin{array}{c}\text { Kecemasan } \\
\text { siswa }\end{array}$ & $\begin{array}{l}\text { hasil } \\
\text { belajar }\end{array}$ \\
\hline \multirow{6}{*}{$\begin{array}{l}\text { Spear } \\
\text { man' } \\
\text { S rho }\end{array}$} & \multirow{3}{*}{$\begin{array}{l}\text { Kecemas } \\
\text { an siswa }\end{array}$} & $\begin{array}{l}\text { Correlation } \\
\text { Coefficient }\end{array}$ & 1,000 &,- 151 \\
\hline & & $\begin{array}{l}\text { Sig. } \\
\text { tailed) }\end{array}$ & - & ,426 \\
\hline & & $\mathrm{N}$ & 30 & 30 \\
\hline & \multirow[t]{3}{*}{$\begin{array}{l}\text { hasil } \\
\text { belajar }\end{array}$} & $\begin{array}{l}\text { Correlation } \\
\text { Coefficient }\end{array}$ &,- 151 & 1,000 \\
\hline & & $\begin{array}{l}\text { Sig. } \\
\text { tailed) }\end{array}$ & ,426 & \\
\hline & & $\mathrm{N}$ & 30 & 30 \\
\hline
\end{tabular}

Output perhitungan korelasi diatas, diketahui jumlah sampel sebanyak 30 memiliki hubungan korelasi ditunjukkan oleh angka hubungan korelasi -0,151 yang artinya terjadi korelasi yang lemah sebesar 0,151 antara kedua variabel. Tanda minus menunjukkan bahwa arah korelasi berlawanan, yang artinya semakin tinggi nilai kecemasan siswa maka semakin rendah hasil belajarnya. Angka sig. (2-tailed) adalah 0,426 lebih besar daripada batas kritis $\alpha=0,05(0,426>0,05)$, berarti kedua variabel memiliki pengaruh yang tidak signifikan maka $H_{0}$ diterima.

\section{Pembahasan}

Ketercapaian suatu pembelajaran umumnya dilihat dari hasil belajar siswa. Hasil belajar ini merupakan penjabaran dari kompetensi yang terdapat dalam kurikulum yang kemudian nantinya akan menjadi indikator pencapaian pembelajaran (Pradipto, 2007, hal. 119). Indikator tersebut yakni dalam segi aspek pengetahuan siswa (kognitif), sikap (afektif), keterampilan (psikomotor), dan somatik. Ketercapaian hasil belajar siswwa di pengaruhi oleh banyak faktor. Faktor-faktor tersebut yakni faktor internal dan faktor ekternal. Tim pengembang Ilmu pendidikan FIP-UPI (2007, hal. 329) mengemukakan bahwa faktor internal merupakan faktor-faktor yang datang dari diri sendiri baik fisikis maupun psikologis sedangkan aktor eksternal merupakan faktor yang datangnya dari luar individu atau bisa disebut dengan lingkungan dari seseorang dimana ia berada seperti keluarga, sekolah, maupun budaya masyarakat. Itu lah kenapa budaya dan pola pikir masyarakat turut mempengaruhi siswa dalam peroses pembelajaran terutama dalam pelajaran matematika. Sebagian masyarakat bahkan mengukur keberhasilan siswa dengan hasil belajar yang diperoleh siswa, tentunya ini menuntut dan menekan siswa untuk mendapatkan hasil belajar yang memuaskan terutama dalam pelajaran matematika. Hal ini menyebabkan timbulnya kecemasan dalam diri siswa dalam pelajaran matematika.

Kecemasan matematika merupakan bentuk perasaan seseorang baik berupa perasaan takut, tegang ataupun cemas dalam menghadapi persoalan matematika atau dalam melaksanakan pembelajaran matematika dengan berbagai bentuk gejala yang ditimbulkan. Orang yang memiliki kecemasan matematika cenderung menganggap matematika sebagai sesuatu yang tidak menyenangkan. Perasaan tersebut muncul karena beberapa faktor baik itu berasal dari pengalaman pribadi terkait dengan guru atau ejekan teman karena tidak bisa menyelesaikan permasalahan matematika kecemasan yang dialami siswa (Wicaksono, Arif dan Saufi, 2013, hal 90). Terkait kecemasan matematika Ashcraft (2002, hal 121) mengemukakan 
bahwa kecemasan matematika umumnya didefinisikan sebagai perasaan ketegangan, ketakutan, atau rasa takut yang mengganggu kinerja matematika. Kecemasan matematika yang dialami siswa umumnya merupakan kecemasan numerik. Kecemasan tersebut yakni ketika siswa dihadapkan dengan masalah matematika, siswa yang memiliki telapak tangan berkeringat, mual, palpitasi jantung, dan pengalaman kelumpuhan pikiran mungkin menderita kecemasan numerik (Morada, 2015, hal 45). Dari berbagai definisi kecemasan matematika tersebut dapat kita simpulkan bahwa kecemasan matematika merupakan suatu kondisi siswa dimana muncul rasa takut, tegang hingga menggalami kelumpuhan pikiran secara numerik yang dialami siswa ketika menghadapi pembelajaran matematika.

Pada penelitian ini menempati frekuensi skor kecemasan siswa paling banyak dengan interval skor 55 hingga 64 pada presentase $30 \%$ yakni 9 dari 30 siswa sedangkan frekuensi skor kecemasan siswa paling sedikit berada pada 2 interval kelas yakni pada interval kelas 35 hingga 44 dan interval kelas 85 hingga 94 pada presentase $3 \%$.

Lebih dari setengah siswa di sekolah tersebut memiliki kecemasan dalam kategori sedang dengan presentase sebesar 57\% dalam pelajaran matematika. Ini artinya mayoritas siswa memiliki kecemasan dalam kategori sedang yang sejalan dengan penemuan Hidayah (2016, hal 54) bahwa mayoritas siswa mengalami kecemasan dalam kategori yang sedang dalam pembelajaran matematika.

Faktor-faktor yang terjadi pada siswa menyebabkan terjadinya perbedaan antara siswa dalam mengalami kecemasan saat pelajaran matematika. Perbedaan tersebut menyebabkan perbedaan tingkatan kecemasan siswa begitupun pengaruhnya terhadap hasil belajar siswa. Terjadi hubungan korelasi yang lemah antara kecemasan dan hasil belajar siswa pada pelajaran matemtika, namun semakin tinggi nilai kecemasan siswa maka semakin rendah hasil belajarnya. Hal ini terjadi apabila tekanan dan paksaan meningkat maka kecemasan akan meningkat pula yang akan berpengaruh pada hasil belajar siswa. Hasil belajar merupakan kemampuan-kemampuan siswa sebagai hasil dari suatu kegiatan yang telah dikerjakan atau diciptakan secara individu atau kelompok setelah menerima perlakuan dari pengajar atau guru (Ibrohim, 2018, hal 18).

Dalam penelitian kecemasan siswa dalam mempengaruhi hasil belajar siswa tidaklah memberikan pengaruh yang signifikan dan cenderung memberikan pengaruh yang negatif. Hasil ini bertolak belakang dengan penelitian Ekawati (2015) bahwa kecemasan mempengaruhi hasil belajar siswa dengan kuat, namun penemuan ini sejalan dengan penemuan Tatiana, Munarka, dan Wiyanti (2018, hal 131) pengaruh antara kecemasan matematika terhadap hasil belajar matematika sangatlah lemah. Penemuan pendukung lainnya datang dari Disai, Dario \& Basaria (2017, hal 565) dikatakan bahwa ada hubungan siginifikan yang negatif antara kecemasan matematika siswa dengan nilai Matematika siswa atau hasil belajar. Perbedaan hasil penemuan tersebut dikarenakan kecemasan bukanlah faktor utama yang memperngaruhi hasil belajar siswa. Selain kecemasan masih banyak faktor lainnya yang mempengaruhi hasil belajar matematika siswa. 


\section{Simpulan dan Saran}

\section{Simpulan}

Kecemasan siswa di salah satu sekolah di Palembang terhadap pembelajaran matematika mayoritas termasuk kedalam kategori sedang dengan presentase sebesar $57 \%$. Terjadi korelasi yang lemah dan tidak ada pengaruh yang signifikan antara kecemasan dan hasil belajar matematika siswa, namun semakin tinggi nilai kecemasan siswa maka semakin rendah hasil belajarnya. Perbedaan hasil penemuan tersebut dikarenakan kecemasan bukanlah faktor utama yang memperngaruhi hasil belajar siswa.

\section{Saran}

Adapun saran berdasarkan hasil penelitian ini adalah diharapkan sebagai pendidik dapat terus berinovasi dalam pembelajaran matematika dan muncul penelitian lanjutan yang dapat menggali faktor lain yang mempengaruhi hasil belajar siswa terhadap pembelajaran matematika.

\section{Daftar Pustaka}

Arvin, B. K. (2000). Nelson Textbook Of Paradiatrics . dalam S. Wahab, Ilmu Kesehatan Anak Nelson (Hal. Vol 1). Jakarta: IKAPI.

Ashcraft, M. H. (2002). Math anxiety: personal, educational,and cognitive consequences. current directions in psycological science, 181-185.

Disai, Dario dan Basaria. (2017). Hubungan antara kecemasan matematika dan selfefficacy dengan hasil belajar matematika siswa SMA Kota Palangka Raya. Jurnal Muara Ilmu Sosial, Humaniora, dan Seni, 1 (2), 556-568.
Ekawati, A. (2015). Pengaruh kecemasan terhadap hasil belajar matematika siswa kelas VII SMPN 13 Banjarmasin. Math Didactic:Jurnal Pendidikan Matematika, 1(3), 41-46.

Fuadiah, n. f. (2017). some difficulties in understanding negative numbers faced by students: a qualitative study applied at secondary schools in Indonesia. International Education Studies, 10(1), 24-38.

Hadiyanto. (2016). Teori dan Pengembangan Iklim Kelas \& Iklim Sekolah. Jakarta: Kencana.

Hidayah, Lely L. N. (2016). Hubungan konsep diri dan kecemasan matematika dengan hasil belajar matematika siswa SMPN 5 Sidoarjo. Skripsi, dipublikasikan. Uin Sunan Ampel Surabaya.

Ibrohim, A. (2018). Jejak Inovasi Pembelajaran Ips: Mengembangkan Profesi Guru Pembelajar. yogyakarta: leutikaprio.

Lou, x. f. (2009). Investigation and Analysis of Mathematics Anxiety in Middle Schoool Students. Journal Of Mathematis Education, 2 (2), 12-19.

Morada, M. H. (2015). Correlation of Numerical Anxiety And Mathematics Performance. Asia Pasific Journal of Multidisciplinary Research, 3(5), 4553.

Noor, F. (2017). Kecemasan dan kemampuan siswa dalam memecahkan masalah matematika. Math Didactic: Jurnal Pendidikan Matematika, 3(3) :169177.

Pradipto, Y. D. (2007). Belajar Sejati VS Kurikulum Nasional. Yogyakarta: Kanisius.

Priyanto, D, Sugianto dan Sri Riyanti. (2017). Tingkat dan faktor kecemasan 
matematika pada siswa sekolah menengah pertama. Jurnal Pendidikan dan Pembelajaran, 6(10), 1-12.

Qausarina, H. (2016). Pengaruh Kecemasan Matematika (math Anxiaety terhadap hasil belajar matematika siswa kelas X negeri 11 Banda Aceh. Skripsi, tidak dipublikasikan.UIN Ar-Raniry Banda Aceh.

Sarwono, J. d. (2012). Statistik Terapan: Aplikasi untuk Riset, Skripsi, Tesis dan Disertasi . Jakarta: PT Alex Media Komputindo.

Sugiono. (2015). Metode Penelitian Pendidikan (Pendekatan Kuantitatif, Kualitatif dan $R \& D)$. Bandung: Alfabeta.

Tatiana, N. P. Munarka dan W. Wiyanti. (2018). Pengaruh kecemasan matematika (mathematics anxiety) terhadap hasil belajar matematika siswa SMP. Aksioma, 9(1) 124-133.

Tim pengembang Ilmu pendidikan FIP-UPI. (2007). Ilmu dan Aplikasi Pendidikan. Bandung: Imperial Bakti Utama.

Wicaksono, A. B. (2013). Mengelola kecemasan siswa dalam pembelajaran matematika. Prosiding, Seminar Nasional Matematika Dan Pendidikan Matematika Yang Di Selenggarakan Oleh FMIPA UNY Pada 9 November 2013. Yogyakarta: Universitas Negeri Yogyakarta. 